\title{
Influência do meio bifásico na multiplicação de gemas e no alongamento de brotos in vitro de Ananas lucidus Miller
}

\author{
NEILIANE SANTIAGO SOMBRA BORGES ${ }^{1}$; DIVA CORREIA ${ }^{2}$ e ADROALDO GUIMARÃES ROSSETTI ${ }^{3}$
}

\begin{abstract}
RESUMO
Este estudo foi realizado no Laboratório de Biotecnologia Vegetal da Embrapa Agroindústria Tropical, em Fortaleza (CE). Nele objetivou-se avaliar a influência do meio de cultura bifásico na multiplicação de gemas e no alongamento de brotos, in vitro, de abacaxi ornamental (Ananas lucidus Miller). $\mathrm{Na}$ multiplicação de gemas, utilizaram-se como explantes, brotos de cultura in vitro, com altura aproximada de $0,5 \mathrm{~cm}$. Utilizou-se o meio MS, solidificado e líquido, suplementado com 1,0 mg. $\mathrm{L}^{-1}$ de 6benzilaminopurina (BAP) e $0,1 \mathrm{mg} \cdot \mathrm{L}^{-1}$ de ácido naftaleno-acético (ANA). O delineamento estatístico utilizado foi o inteiramente casualizado com os seguintes tratamentos: acréscimos de $10 \mathrm{~mL}$ de meio líquido/frasco nos períodos de cultivo $0 ; 15 ; 30 ; 15$ e 30; 30 e 60 e, a cada 15 dias durante 75 dias, com 14 repetições e 6 explantes/parcela. Avaliaram-se os pesos de matéria fresca e de matéria seca aos 90 dias de cultivo. No mesmo período, as culturas de cada tratamento foram transferidas para o meio de cultura de Murashige \& Skoog (MS) solidificado com 0,4\% $(\mathrm{p} / \mathrm{v})$ de ágar e suplementado com $0,01 \mathrm{mg} . \mathrm{L}^{-1} \mathrm{de}$ ANA para o alongamento dos brotos, utilizando, como explante, aglomerado de gemas com aproximadamente $0,5 \mathrm{~cm}$ de diâmetro. Cada tratamento foi composto por 6 repetições e 6 explantes/parcela, dispostos em delineamento inteiramente casualizado. Realizaram-se três subcultivos sucessivos para o mesmo meio "novo" a cada 30 dias. Aos 90 dias de cultivo em meio de alongamento avaliaram-se o núme-
\end{abstract}

ro de brotos/explante e as porcentagens de número de brotos e de brotos enraizados em quatro amplitudes de altura. Os maiores valores médios para pesos de matéria fresca $(913,7 \mathrm{mg}$ /explante) e matéria seca $(69,1 \mathrm{mg} /$ explante) foram obtidos com o acréscimo de $10 \mathrm{~mL}$ de meio líquido aos 30 dias de cultivo. Os acréscimos de meio líquido efetuados aos 15 e 30 dias de cultivo proporcionaram a maior média de número de brotos (32,6 brotos/explante) aos 90 dias de cultivo em meio de alongamento de brotos. Em todos os tratamentos, as maiores porcentagens para o número de brotos e de brotos enraizados encontravam-se na amplitude de altura entre $1,0 \mathrm{~cm}$ e 2,0 cm.

Palavras-chave: abacaxi ornamental, micropropagação, meio de cultura bifásico.

\section{ABSTRACT \\ Influence of biphasic tissue culture medium in the bud multiplication and on the shoot elongation in vitro of Ananas lucidus Miller}

The study was conducted at Biotechnology Laboratory of Embrapa Tropical Agroindustry in Fortaleza (Ceará), Brazil. The objective of this workwas to evaluate influence of biphasic tissue culture medium in the bud multiplication and on the shoot elongation in vitro of ornamental pineapple (Ananas lucidus Miller). It was used bud multiplication explants of in vitro culture with $0,5 \mathrm{~cm}$ of height. The tissue cul-

\footnotetext{
${ }^{1}$ Doutoranda em Fitotecnia, Faculdade de Agronomia, Universidade Federal do Ceará. Av. Mister Hull, s/n - Pici, 600455-760, Fortaleza (CE). Email: nssborges@bol.com.br

2 Doutoranda em Recursos Florestais ESALQ/USP: Embrapa Agroindústria Tropical, Caixa Postal 3761, 60511-110, Fortaleza (CE). E-mail: diva@cnpat.embrapa.br

3 Embrapa Agroindústria Tropical.
} 
ture medium used was MS, solid and liquid, supplemented with BAP $\left(1 \mathrm{mg} \cdot \mathrm{L}^{-1}\right)$ and ANA $\left(0,1 \mathrm{mg} \cdot \mathrm{L}^{-1}\right)$. The statistic delineation was completely randomized design with the following treatments: additions of $10 \mathrm{~mL}$ of liquid tissue culture medium per glass in periods of cultive: at 0 day, 15 days, 30 days, 15 and 30 days, 30 and 60 days, and in each 15 days for 75 days, with 14 replicated and 6 explants per plot. The evaluated parameters were: fresh weight matter and dry weight matter at 90 days of culture. In this same period the cultures of each treatments were removed for a basic tissue culture medium MS solidified with agar $0,4 \%(\mathrm{p} / \mathrm{v})$ and supplemented with ANA $(0,01$ $\left.\mathrm{mg} . \mathrm{L}^{-1}\right)$ for shoot elongation, using as explants clusters of buds with $0,5 \mathrm{~cm}$ of diameter. The statistic delineation was completely randomized design with 6 replicated and 6 explants per plot. There were three successive subcultives for this same new medium in each 30 days. At 90 days of culture in the shoots elongation medium were evaluated the number of shoot/ explant, shoot number percentage and percentage of shoot rooting in four amplify of height. The highest value for fresh weight matter $(913,7 \mathrm{mg} /$ explant) and dry weight matter $(69,1 \mathrm{mg} /$ explant $)$ were obtained with addition of $10 \mathrm{~mL}$ in the liquid tissue culture medium at 30 days of culture. The additions of liquid tissue culture medium at 15 and 30 days of culture provided the highest mean of number of shoot (32.6 shoot/explant) at 90 days of culture in the shoot elongation medium. In all treatments the highest percentage of number of shoot and percentage of shoot rooting were observed in amplify of $1,0 \mathrm{~cm}$ to 2,0 $\mathrm{cm}$ of height.

Key words: ornamental pineapple, micropropagation, biphasic tissue culture medium.

\section{INTRODUÇÃO}

O abacaxi ornamental (Ananas lucidus Miller) caracteriza-se por ser terrestre, desenvolvendo-se, geralmente, em campo aberto sob alta luminosidade, em ambientes de solos arenosos e de clima tropical. Apresenta folhagens rígidas, eretas, sem espinhos e de coloração púrpura. As folhas crescem até $1,0 \mathrm{~m}$ de comprimento com largura de aproximadamente $3,5 \mathrm{~cm}$, em margens lisas e ápice de ponta aguda (SMITH \& DOWNS, 1979), porém, mais finas quando comparadas com a folhagem de abacaxi comestível. Apresenta inflorescência globosa, sustenta brácteas com flores completas e pequenas (LEAL \& AMAYA, 1991). Sua infrutescência é vermelha, medindo de 8 a $10 \mathrm{~cm}$, disposta na posição apical da haste que pode medir até $80 \mathrm{~cm}$ (CORREIA et al., 1999a).

Outros nomes utilizados para esse abacaxi ornamental são: pitte (SMITH \& DOWNS, 1979), curua, curaua (FOUQUE, 1981), curaguata (CAULIN, 1966) e curaua de Amazônia (MEDINA, 1978). Aparentemente, foi originado ao longo da baixa e úmida margem da Bacia Amazônica (BAKER \& COLLINS, 1939; SMITH, 1971).

O A. lucidus tem apresentado grande interesse para os paisagistas e floricultores do Brasil, como, também, do exterior, por ser uma planta ornamental de região tropical, exótica e rústica. Atualmente, o Brasil é o único país que possui plantios comerciais de $A$. lucidus. Um deles está localizado no município de Paracuru (CE) e objetiva a flor de corte com produção superior a 16 mil hastes/mês direcionada à exportação para os mercados da Alemanha, da Holanda e Estados Unidos (CORREIA \& BORGES, 2001). Outro plantio localiza-se em Goiânia (GO) e atende ao mercado de paisagismo (NOGUEIRA, 2001). Adicionalmente, tem potencial para obtenção de fibras caracterizadas como duras e resistentes (LEAL \& AMAYA, 1991).

Normalmente, os plantios de $A$. lucidus têm sido feitos com mudas propagadas vegetativamente, similar às utilizadas em plantios de abacaxi comestível e retiradas de diferentes partes da planta: coroa, filhote e rebentão. Em abacaxizeiro comestível, esse processo pode ocasionar a disseminação do patógeno causador da fusariose, propiciando perdas de até $80 \%$ dos frutos (CABRAL et al., 1985). A técnica de cultura de tecidos apresenta-se como uma alternativa viável na propagação do abacaxizeiro, produzindo mudas vigorosas, livres de patógenos, em larga escala, em curto período e espaços reduzidos (SÁ et al., 2001). Diante disso, muitos protocolos têm sido desenvolvidos para multiplicar, in vitro, os principais cultivares de abacaxi comestível objetivando, além de alta taxa de multiplicação, sua eficácia (FEUSER et al., 2001; ALMEIDA et al., 2002). Esta eficácia pode ser avaliada, normalmente, pela taxa média de multiplicação de brotos ao longo dos subcultivos e pelo número final de mudas micropropagadas com as mesmas características genéticas da planta matriz (GRATTAPAGLIA \& MACHADO, 1998). 
O presente trabalho teve como objetivo avaliar a influência do meio bifásico na multiplicação de gemas e no alongamento de brotos de A. lucidus in vitro.

\section{MATERIAL E MÉTODOS}

O estudo foi realizado no Laboratório de Biotecnologia Vegetal da Embrapa Agroindústria Tropical, em Fortaleza, Ceará.

\section{Plantas matrizes e fonte de explante}

Plantas de A. lucidus Miller, com aproximadamente 1 ano de idade, foram fornecedoras de coroas, das quais, gemas axilares serviram como fonte de explante.

\section{Assepsia dos explantes}

As coroas foram desfolhadas, lavadas em água corrente e desinfestadas com $2 \%(\mathrm{v} / \mathrm{v})$ de solução comercial de hipoclorito de sódio durante 5 minutos. Em câmara asséptica, foram desinfestadas com $70 \%$ (v/v) de solução de álcool durante 2 minutos, seguida de imersão com $1 \%$ (v/v) de solução comercial de hipoclorito de sódio com adição de $0,01 \%$ (v/ v) de Tween 20 durante 15 minutos. Posteriormente, foram elas submetidas a três lavagens sucessivas em água destilada e esterilizada em autoclave a $121^{\circ} \mathrm{C}$ sob pressão de $1,05 \mathrm{~kg} . \mathrm{cm}^{-2}$ durante 40 minutos.

\section{Isolamento, estabelecimento e multiplicação de gemas axilares in vitro}

Gemas axilares foram retiradas das coroas, inoculadas individualmente em tubos de cultura (25 $\mathrm{mm} \times 150 \mathrm{~mm}$ ) contendo meio de cultura MS (MURASHIGE \& SKOOG, 1962), suplementado com $1 \mathrm{mg} . \mathrm{L}^{-1}$ de 6-benzilaminopurina (BAP), 0,01 mg. $\mathrm{L}^{-1}$ de ácido naftalenoacético (ANA), $2 \mathrm{mg} . \mathrm{L}^{-1} \mathrm{de}$ ácido giberélico $\left(\mathrm{GA}_{3}\right), 30$ g.L. $\mathrm{L}^{-1}$ de sacarose e solidificado com $0,4 \%(\mathrm{p} / \mathrm{v})$ de ágar "Vetec", segundo CORREIA et al. (1999a). O pH do meio de cultura foi ajustado para 5,8 antes da esterilização em autoclave a $121^{\circ} \mathrm{C}$ e pressão de $1,05 \mathrm{~kg} . \mathrm{cm}^{-2}$ durante 15 minutos.

As culturas isoladas foram mantidas à temperatura de $27^{\circ} \mathrm{C} \pm 1^{\circ} \mathrm{C}$. Permaneceram no escuro durante os primeiros 7 dias de cultivo e, posteriormente, foram submetidas à intensidade luminosa de 1.000 lux com fotoperíodo de 12 horas de luz e 12 horas no escuro. Nessa condição ambiental, conduziram-se as demais etapas deste estudo.
As culturas de gemas axilares foram subcultivadas a cada 30 dias, durante 3 meses, para o mesmo meio básico utilizado na etapa de isolamento de gemas axilares.

Posteriormente, obteve-se a multiplicação de gemas em meio de cultura básico, suplementado com 1,0 mg.L $\mathrm{L}^{-1}$ de BAP e 0,1 mg.L ${ }^{-1}$ de ANA, 30 g.L.- de sacarose e solidificado com $0,4 \%(\mathrm{p} / \mathrm{v})$ de ágar "Vetec" (CORREIA et al., 1999a), realizando-se cinco subcultivos a cada 30 dias.

\section{Experimento}

\section{Fase de multiplicação de gemas}

$\mathrm{O}$ experimento foi desenvolvido tendo, como explantes, brotos com altura aproximada de $0,5 \mathrm{~cm}$, oriundos do quinto subcultivo da fase de multiplicação de gemas. A média de peso de matéria seca inicial $(3,5 \mathrm{mg})$ foi estabelecida por meio de amostragem composta por 20 explantes, procedendo-se à secagem e pesagem de cada explante de acordo com CORREIA (1993). O meio de cultura básico foi o mesmo utilizado na multiplicação de gemas, solidificado com $0,4 \%(\mathrm{p} / \mathrm{v})$ de ágar "Vetec" e líquido. Distribuíram-se $20 \mathrm{~mL}$ do meio com acréscimo de ágar em frasco com capacidade para $220 \mathrm{~mL}$ e vedados com tampas de polipropileno.

O delineamento estatístico foi inteiramente casualizado, sendo os tratamentos representados por acréscimo de $10 \mathrm{~mL}$ de meio líquido/frasco nos períodos de cultivo 0 (testemunha); $15 ; 30 ; 15$ e $30 ; 30$ e 60; e a cada 15 dias, durante 75 dias, com 14 repetições contendo um frasco por parcela e 6 explantes em cada frasco. Os acréscimos de meio líquido foram realizados fazendo uso de pipetas esterilizadas.

Aos 90 dias de cultivo, retirou-se, aleatoriamente, um explante de cada parcela para a avaliação dos pesos de matéria fresca (PMF) e de matéria seca (PMS).

\section{Fase de alongamento de gemas}

Culturas de cada tratamento da fase de multiplicação de gemas foram subcultivadas, aos 90 dias de cultivo, para meio de cultura MS solidificado com 0,4\% (p/v) de ágar "Vetec" e suplementado com 0,01 mg.L.-1 de ANA (CORREIA et al., 1999b) para o alongamento dos brotos. Aglomerados de gemas tipo "clusters", com aproximadamente $0,5 \mathrm{~cm}$ de diâmetro, serviram como explantes. Os frascos e volumes de meios neles distribuídos foram idênticos aos utilizados na fase anterior. 
Para cada tratamento prepararam-se 6 repetições contendo 1 frasco por parcela e 6 explantes em cada frasco dispostos em delineamento inteiramente casualizado. Foram realizados três subcultivos para o mesmo meio "novo" a cada 30 dias, mantendo-se a característica para tamanho do explante, número de repetições por tratamento, tamanho da parcela e de explantes por parcela, a cada subcultivo.

Aos 90 dias de cultivo em alongamento de brotos, todos os explantes foram avaliados quanto ao número de brotos por explante e quanto às porcentagens de número de brotos e de brotos enraizados, com base em quatro amplitudes de altura $(0,5$ a $1,0 \mathrm{~cm} ; 1,0 \mathrm{a}$ $2,0 \mathrm{~cm} ; 2,0$ a $3,0 \mathrm{~cm}$ e 3,0 a $4,0 \mathrm{~cm}$ ) respectivamente.

Os efeitos dos tratamentos nas variáveis estudadas (PMF e PMS) foram avaliados mediante análise da variância e as médias dos tratamentos, pelo teste de Tukey a $5 \%$ de probabilidade. Para o número de brotos por explante, efetuou-se uma análise de regressão. Análises descritivas foram realizadas para as porcentagens de número de brotos e de brotos enraizados, ambas baseadas em quatro amplitudes de altura dos brotos.

\section{RESULTADOS}

As análises da variâncias dos valores do PMF e do PMS mostraram que estes são significativos pelo teste $\mathrm{F}(\mathrm{p}<0,0001)$. O crescimento e desenvolvimento de gemas variou de explante para explante em todos os tratamentos, formando aglomerados de brotos, com tamanhos variados, nos quais a maioria dos brotos se encontrava com altura abaixo de $0,5 \mathrm{~cm}$. Isso contribuiu para haver maior amplitude entre os valores tanto para PMF quanto para PMS, justificando os altos coeficientes de variação, $40,0 \%$ e 33,2\%, respectivamente (Tabela 1). As médias gerais para PMF e PMS foram 542,36 mg e 41,33 mg por explante respectivamente (Tabela 1), representando um aumento de 11,8 vezes para o PMS aos 90 dias de cultivo, em meio de multiplicação de gemas.

A maior média observada para PMF $(913,7 \mathrm{mg} /$ explante) foi obtida com um acréscimo de meio líquido aos 30 dias de cultivo. Não diferenciou estatisticamente, porém, das médias dos tratamentos sem acréscimo de meio líquido (683,8 mg/explante) e com apenas um acréscimo de meio líquido aos 15 dias (589,1 $\mathrm{mg}$ /explante) (Tabela 1). Maior média para PMS foi alcançada com um acréscimo de meio lí- quido aos 30 dias de cultivo (69,1 mg/explante), a qual diferiu estatisticamente dos demais tratamentos (Tabela 1), expressando um aumento de 19,7 vezes de PMS em 90 dias de cultivo. Os demais tratamentos não diferenciaram estatisticamente quanto ao PMS (Tabela 1).

Tabela 1. Valores médios para peso de matéria fresca e de matéria seca de explantes de abacaxi ornamental (Ananas lucidus Miller), na multiplicação de gemas em meio de cultura MS bifásico obtidos aos 90 dias de cultivo

\begin{tabular}{lll}
\hline \multirow{2}{*}{$\begin{array}{c}\text { Acréscimo de meio } \\
\text { líquido em diferentes } \\
\text { períodos de cultivo }\end{array}$} & \multicolumn{2}{c}{ Peso de matéria } \\
\cline { 2 - 3 } & & fresca \\
\cline { 2 - 3 } Sem acréscimo de meio & $683,8 \mathrm{ab}$ & $44,8 \mathrm{~b}$ \\
Aos 15 dias & $589,1 \mathrm{abc}$ & $40,7 \mathrm{~b}$ \\
Aos 30 dias & $913,7 \mathrm{a}$ & $69,1 \mathrm{a}$ \\
Aos 15 e 30 dias & $527,4 \mathrm{bc}$ & $37,3 \mathrm{~b}$ \\
Aos 30 e 60 dias & $217,9 \mathrm{c}$ & $25,5 \mathrm{~b}$ \\
A cada 15 dias & $322,3 \mathrm{bc}$ & $30,6 \mathrm{~b}$ \\
Média geral (mg) & 542,3 & 41,33 \\
CV (\%) & 40,0 & 33,23 \\
\hline
\end{tabular}

Médias seguidas pela mesma letra, nas colunas, não diferem estatisticamente pelo teste de Tukey a $5 \%$ de probabilidade.

Na Figura 1 podem-se observar respostas diferenciadas à multiplicação de brotos em razão dos tratamentos utilizados anteriormente para tal finalidade. Explantes oriundos do tratamento ao qual acrescentaram-se meios líquidos aos 15 e 30 dias de cultivo, na multiplicação de gemas, desenvolveram a maior média de número de brotos (32,6 brotos/explante) aos 90 dias de cultivo, em meio de alongamento. Respostas similares para médias de número de brotos por explante foram obtidas com 1 acréscimo de meio líquido realizado aos 15 dias de cultivo (24,0 brotos/explante) ou aos 30 dias de cultivo $(23,4$ brotos/explante) ou com 2 acréscimos de meio líquido, realizados aos 30 e 60 dias de cultivo (25,8 brotos/ explante) (Figura 1). Isso pode indicar que 1 ou 2 acréscimos de meio líquido, realizados até 30 dias ou aos 30 e 60 dias de cultivo foram favoráveis ao 
crescimento e desenvolvimento de gemas in vitro, ao passo que as menores médias de número de brotos (14,8 e 17,8 brotos/explante) foram obtidas em culturas procedentes dos tratamentos nos quais não houve acréscimo de meio líquido e com maior número de acréscimos (cinco), respectivamente, em 90 dias de cultivo, demonstrando não serem favoráveis à formação de brotos (Figura 1).

Para a variável amplitude de altura de brotos, pode-se observar que, em todos os tratamentos, as maiores porcentagens de número de brotos encontravam-se na amplitude entre $1,0 \mathrm{~cm}$ e $2,0 \mathrm{~cm}$ de altura. Nesta amplitude de altura, acréscimos de meio líquido aos 15 dias e, aos 15 e 30 dias de cultivo apresentaram $80,0 \%$ e $70,0 \%$ respectivamente, ao passo que as menores porcentagens de número de brotos foram obtidas em amplitude entre $3,0 \mathrm{~cm}$ e $4,0 \mathrm{~cm}$ de altura (Figura 2). Maior uniformidade para porcentagens de número de brotos nas amplitudes de altura de brotos foi observada em culturas procedentes de tratamentos em que houve acréscimos de meio líquido aos 30 e 60 dias e a cada 15 dias (Figura 2).
Durante o alongamento de brotos, a maior parte dos brotos desenvolveu raízes independentemente do tratamento de origem. Maiores porcentagem de brotos enraizados encontravam-se na amplitude de 1,0 a $2,0 \mathrm{~cm}$ de altura em que a maior porcentagem $(52,0 \%)$ foi alcançada com acréscimo de meio líquido aos 30 dias de cultivo (Figura 3).

\section{DISCUSSÃO}

O valores de PMF e PMS apresentaram grande amplitude de variação aos 90 dias de cultivo, independentemente de acréscimos ou não de meio líquido. Isso pode ter contribuído para a obtenção de um coeficiente de variação elevado tanto para PMF quanto para PMS. O aumento do número de explantes utilizados na amostragem poderia reduzir os valores desses coeficientes de variação e/ou a preferência pelo delineamento em blocos ao acaso, o qual reduziria o erro experimental. Outrossim, as taxas de multiplicação de gemas podem estar relacionadas ao potencial genético do material, ao valor nutricional do

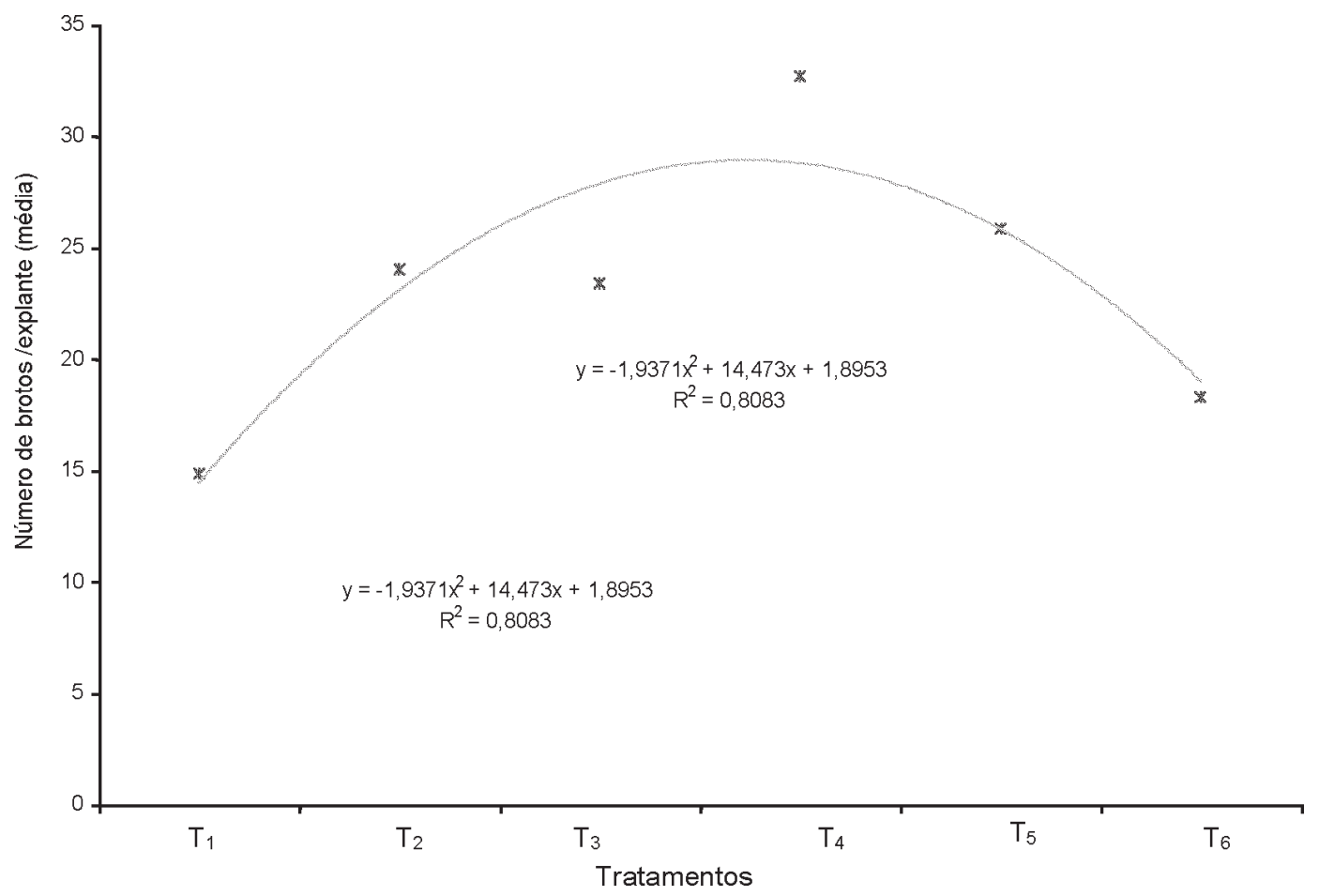

$T_{1}$ : Ausência de meio líquido; $T_{2}$ : Acréscimo de meio líquido aos 15 dias; $T_{3}$ : Acréscimo de meio líquido aos 30 dias; $T_{4}$ : Acréscimo de meio líquido aos 15 e 30 dias; $T_{5}$ : Acréscimo de meio líquido aos 30 e 60 dias; $T_{6}$ : Acréscimo de meio líquido a cada 15 dias

Figura 1. Número médio de brotos de abacaxi ornamental (Ananas lucidus Miller) na fase de alongamento, cultivados durante os primeiros 90 dias em diferentes tratamentos para a multiplicação de gemas, e subcultivados para meio de alongamento de brotos em que permaneceram por mais 90 dias de cultivo 


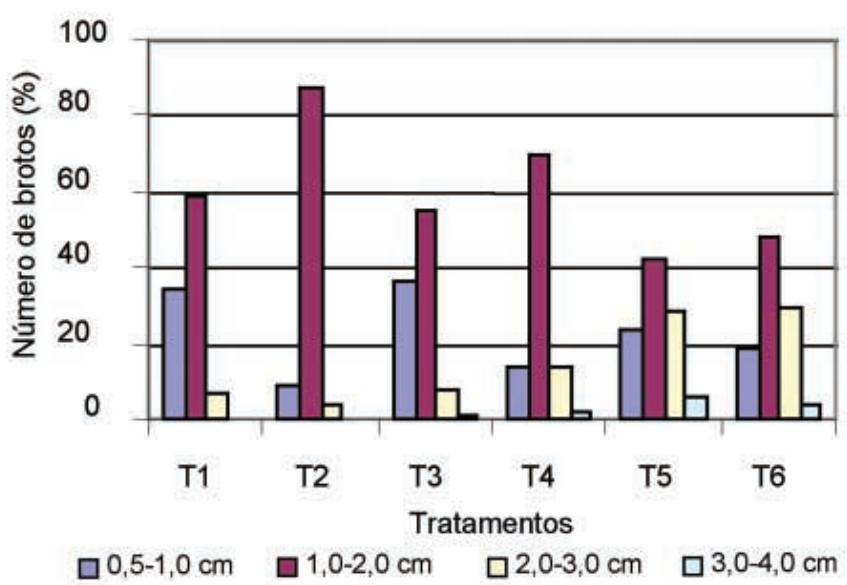

$\mathrm{T}_{1}$ : Ausência de meio líquido

$\mathrm{T}_{2}$ : Acréscimo de meio líquido aos 15 dias

$\mathrm{T}_{3}$ : Acréscimo de meio líquido aos 30 dias

$\mathrm{T}_{4}$ : Acréscimo de meio líquido aos 15 e 30 dias

$\mathrm{T}_{5}$ : Acréscimo de meio líquido aos 30 e 60 dias

$\mathrm{T}_{6}$ : Acréscimo de meio líquido a cada 15 dias

Figura 2. Porcentagem de número de brotos de abacaxi ornamental (Ananas lucidus Miller) em quatro amplitudes de altura, cultivados durante os primeiros 90 dias em diferentes tratamentos para a multiplicação de gemas e subcultivados para meio de alongamento de brotos nos quais permaneceram por mais 90 dias de cultivo

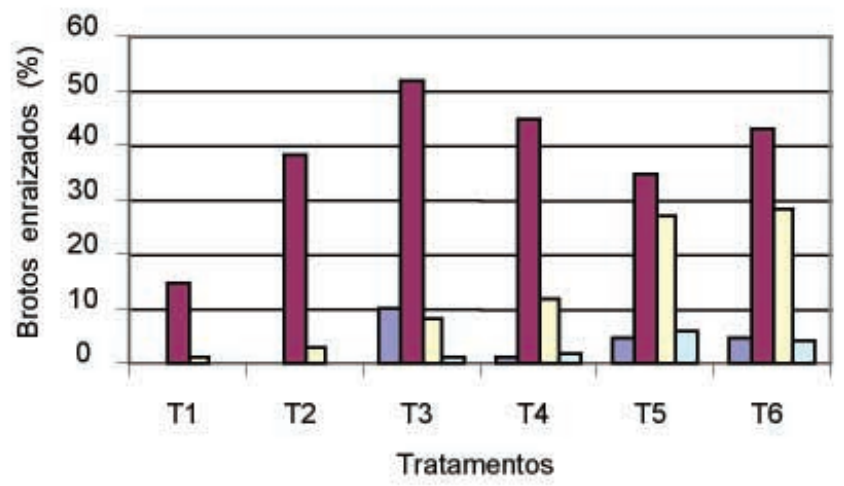

\section{$0,5-1,0 \mathrm{~cm} \quad \square 1,0-2,0 \mathrm{~cm} \quad \square 2,0-3,0 \mathrm{~cm}$ \\ $\mathrm{T}_{1}$ : Ausência de meio líquido \\ $\mathrm{T}_{2}$ : Acréscimo de meio líquido aos 15 dias \\ $\mathrm{T}_{3}$ : Acréscimo de meio líquido aos 30 dias \\ $\mathrm{T}_{4}$ : Acréscimo de meio líquido aos 15 e 30 dias \\ $\mathrm{T}_{5}$ : Acréscimo de meio líquido aos 30 e 60 dias \\ $\mathrm{T}_{6}$ : Acréscimo de meio líquido a cada 15 dias}

$3,0-4,0 \mathrm{~cm}$

Figura 3. Porcentagem de brotos enraizados de abacaxi ornamental (Ananas lucidus Miller) em quatro amplitudes de altura, cultivados durante os primeiros 90 dias em diferentes tratamentos para a multiplicação de gemas e subcultivados para meio de cultura e sua capacidade de difusão, às condições ambientais (RAO \& VENKATESWARA, 1985) e microambientais para o crescimento in vitro (CORREIA, 1993), bem como, à manipulação e ao preparo do explante (GRATTAPAGLIA \& MACHADO, 1998).

Tais referências podem justificar os diferentes ganhos de PMF e PMS durante a fase de multiplicação de gemas em 90 dias de cultivo. O manejo in vitro, entretanto, empregado com acréscimos de meio líquido em diferentes períodos de cultivo e de volumes adicionados, foi, provavelmente, responsável pela variação do crescimento de brotos na fase subseqüente em razão de um efeito residual. Maiores ganhos de PMF e PMS, porém, obtidos com um acréscimo de meio líquido aos 30 dias de cultivo sob efeito do meio de multiplicação de gemas, não proporcionaram maiores médias de número de brotos/ explante na fase de alongamento, ao passo que, acréscimos de meio líquido em períodos mais curtos, aos 15 e 30 dias de cultivo, sobre um volume fixo de meio sólido, promoveram $54,6 \%$ a mais de brotos em relação ao cultivo somente em meio sólido, na etapa de alongamento de brotos.

Embora tenham sido realizados três subcultivos, um a cada 30 dias nesta etapa, o meio MS solidificado apresentou a menor média de número de brotos. Nesse caso, o uso de ágar como agente solidificante do meio pode estar favorecendo a existência de uma barreira junto aos processos de difusão e de absorção de nutrientes, proporcionando a redução no crescimento das culturas. Adicionalmente, esse produto, dependendo da quantidade utilizada, da qualidade e da origem, pode apresentar na sua composição substâncias inibidoras que interferem no crescimento e desenvolvimento de gemas, conforme observou DEBERGH (1983) em culturas de Cynara scolymus e MACRAE \& STADEN (1990) na multiplicação e no alongamento de brotos de Eucalyptus grandis.

Por outro lado, maior número de acréscimos de meio líquido realizados a cada 15 dias reduziu as médias de PMF e PMS e de número de brotos em $45,4 \%$, quando comparada à média alcançada em meio sólido, na fase de alongamento. Uma possível formação de substâncias inibidoras do crescimento, originárias do metabolismo do explante e liberadas ao meio de cultivo sólido e/ou líquido, poderia estar influenciando nas respostas organogenéticas. Não foi observado, todavia, característica de hiperidria tan- 
to na etapa de multiplicação quanto de alongamento de brotos. Para A. comosus cv. Smooth Cayenne, CABRAL et al. (1984) afirmam que a formação de gemas foi favorecida em meio líquido suplementado com BAP, ANA e AIB. GUERRA et al. (1999) obtiveram 19,7 brotos/explante para a cv. Primavera, em meio de cultura MS líquido suplementado com ANA $(2,7 \mu \mathrm{M})$ e BAP $(4,4 \mu \mathrm{M})$.

$\mathrm{O}$ meio de cultura sólido suplementado com ANA $\left(0,01 \mathrm{mg} . \mathrm{L}^{-1}\right)$, utilizado na fase de alongamento, promoveu pouco crescimento e enraizamento dos brotos. Acréscimos de meio líquido, entretanto, contendo BAP $\left(1,0 \mathrm{mg} . \mathrm{L}^{-1}\right)$ e ANA $\left(0,1 \mathrm{mg} . \mathrm{L}^{-1}\right)$, provavelmente tenham causado um efeito residual, desencadeando, na fase de alongamento, uma relação auxina/citocinina favorável ou menos favorável à multiplicação, ao alongamento e ao enraizamento de brotos, dependendo do período e da freqüência de acréscimos. Tais respostas organogenéticas concordam com os resultados de um dos primeiros estudos da aplicação de hormônios exógenos em cultura de tecidos vegetais conduzidos por SKOOG \& MILLER (1957) na qual foi demonstrado que a auxina age em sinergia com a citocinina para estimular a divisão celular, e que essas classes hormonais atuam de forma antagônica no controle da iniciação de ramos e de raízes.

Acresce que citocininas interagem com nitrogênio, provavelmente, por meio da regulação das enzimas do metabolismo de nitrogênio, existindo evidências de que essa classe de hormônio é ativadora da enzima nitrato redutase (BANOWETZ, 1992; SAMUELSON et al.,1995), podendo, assim, favorecer o crescimento dos brotos.

A aplicação, entretanto, de concentrações elevadas de auxina e de citocinina pode promover inibição do crescimento de órgãos vegetais. Em ambos os casos, grande parte dessa inibição é decorrente da indução da produção de etileno no nível da enzima ACC sintase (MCKEON et al.,1995). Isso poderia ser um dos fatores que causaram o pouco desenvolvimento das culturas nas quais houve acréscimos de meios líquido em maior freqüência.

\section{REFERÊNCIAS BIBLIOGRÁFICAS}

ALMEIDA, W. A. B. de et al. Optimization of a protocol for the micropropagation of pineapple. Revista Brasileira de Fruticultura, Jaboticabal, v.24, n.2, p.296-300, 2002.
BAKER, K. \& COLLINS, J. L. Notes on the distribution and ecology of Ananas and Pseudoananas in South America. American Journal Botanic, Columbia, 1939. v.26, p.697-702,

BANOWETZ, G. M. The effects of endogenous cytokinin content on benzyladenine enhaced nitrate reductase induction. Physiologia Plantarum, Copenhagen, 1992. v.86, p.341-348,

CABRAL, J. R. S.; CUNHA, G. A. P. \& RODRIGUES, E. M. Micropropagação de abacaxizeiro. In: CONGRESSO BRASILEIRO DE FRUTICULTURA, 5, Florianópolis, 1983. Anais... Florianópolis: SBF, 1984. v.1, p.124-127.

CABRAL, J. R. S.; MATOS, A. P. \& SOUTO, G. F. Reação de germoplasma de abacaxi à inoculação com Fusarium moniliforme var. Subglutinans. Pesquisa Agropecuária Brasileira, Brasília, v.20, n.7, p.787-791, 1985.

CAULIN, A. História corográfica, natural y evangélica de la Nueva Andalucía. Caracas: Biblioteca de la Academia Nacional de la Historia. 1966. 81p.

CORREIA, D. Crescimento e desenvolvimento de gemas in vitro de Eucalyptus spp. em meio líquido e sólido. Piracicaba: ESALQ-USP, 1993. 113p. Dissertação (Mestrado em Ciências Florestais)

CORREIA, D. et al. Avaliação da multiplicação in vitro do abacaxi ornamental (Ananas lucidus Miller). Fortaleza: Embrapa Agroindústria Tropical, 1999a. 2p. (Pesquisa em Andamento, 56.)

CORREIA, D. et al. Influência do meio de cultura sólido e líquido no alongamento de brotos in vitro de abacaxi ornamental (Ananas lucidus Miller). Fortaleza: Embrapa Agroindústria Tropical, 1999b. 3p. (Pesquisa em Andamento, 57.)

CORREIA, D. \& BORGES, N. S. S. Obtenção de mudas micropropagadas de abacaxi ornamental na Embrapa Agroindústria Tropical. In: SIMPÓSIO DE INOVAÇÕES TECNOLÓGICAS E GERENCIAIS, 1, Fortaleza, 2001. Resumos... Fortaleza: Embrapa Agroindústria Tropical/SINDIFRUTA, 2001. 191p.

DEBERGH, P. C. Effects of agar brand and concentration on the tissue culture medium. Physiologia Plantarum, Copenhagen, v.59, p.270-276, 1983. 
FEUSER, S.; NODARI, R. O. \& GUERRA, M. P. Eficiência comparativa dos sistemas de cultura estacionária e imersão temporária para micropropagação do abacaxizeiro. Revista Brasileira de Fruticultura, Jaboticabal, v.23, n.1, p.6-10, 2001.

FOUQUE, A. Las plantas medicinales presentes en foret Guayanaise. Fruits, Paris, v.36, n.9, p.503-528, 1981.

GRATtAPAGLiA, D. \& MACHADO, M. A. Micropropagação. In: TORRES, A. C., CALDAS, L. S. (Eds). Cultura de tecidos e transformação genética de plantas. Brasília: Embrapa-CNPH, 1998. p.183-260.

GUERRA, M. P. et al. Establishment of a regenerative protocol for the pineapple micropropagation. Pesquisa Agropecuária Brasileira, Brasília, v.34, n.9, p.1557$1563,1999$.

LEAL, F. \& AMAYA, L. The Curagua (Ananas lucidus, Bromeliaceae) Crop in Venezuela. Economic Botany, New York, v.45, n.2, p.216-224, 1991.

MACRAE, S. \& STADEN, J. van. In vitro culture of Eucalytus grandis: effect of gelling agents on propagation. Journal Plant Physiologica, Congella, v.137, p.249-251, 1990.

MCKEON, T.A.; FERNÁNDES-MACULET, J. C. \& YANG, S. F. Biosynthesis and metabolism of ethylene. In: DAVIS, P. J. (Ed.) Plant hormones: physiology, biochemistry and molecular biology. Dorderecht, Kluwer Academic Publishers, 1995. p.118-139.

MEDINA, J. C. Abacaxi - da cultura ao processamento e comercialização. Governo do Estado de São Paulo. Secretaria de Agricultura, Instituto de Tecnologia de Alimentos, Ser. Frutas Trop., 1978, v.2, p.5-67.
MURASHIGE, T. \& SKOOG, F. A. A revised medium for rapid growth and bioassay with tobacco tissue culture. Phisiologia Plantarum, Copenhagen, v.15, n.3, p. 47397, 1962.

NOGUEIRA, D. Exuberantes flores tropicais: Embrapa estuda plantas exóticas para exportação. Jornal do Brasil, 2001. Disponível em: <http://jbonline.terra.com.br/ jb/papel/ciencia/2001/01/28/jorcie20010128001.html $>$. Acesso em: 28 jan. 2001.

RAO, K. S. \& VENKATESWARA, R. Tissue culture of forest trees: clonal multiplication of Eucalyptus grandis L. Plant Science, Sofia, v.40, p.51-55, 1985.

SÁ, M. E. L. et al. Propagação in vitro de abacaxi (Ananas comosus) por meio de segmentos estiolados. Revista Brasileira de Fruticultura, Jaboticabal, v.23, n.1, p.1720, 2001.

SAMUELSON, M. E.; CAMPBELL, W. H. \& LARSSON, C. M. The influence of cytokinins in nitrate regulation of nitrate reductase activity and expression in barley. Phisiologia Plantarum, Copenhagen, v.93, p.533-539, 1995.

SKOOG, F. \& MILLER, C. O. Chemical regulation of growth and organ formation in plant tissues cultured in vitro. Symposium Society Experimental Biology, Oxford, v.11, p.118-231, 1957.

SMITH, L. B. Flora de Venezuela, Bromeliacea. Caracas: Ministério da Agricultura, Instituto Botânico, 1971. v.12, p.361.

SMITH, L. B. \& DOWNS, R. J. Bromelioideae (Bromeliaceae), New York, v.14, n.3, p.1493-2142, 1979. 